\title{
Growth and Development of Grafted Cucumber Transplants as Affected by Seedling Ages of Scions and Rootstocks and Light Intensity during Their Cultivation in a Closed Production System
}

\author{
Yurina Kwack ${ }^{1}$, Seon Woo Park ${ }^{2}$, and Changhoo Chun ${ }^{1,2^{*}}$ \\ ${ }^{1}$ Research Institute of Agriculture and Life Science, Seoul National University, Seoul 151-921, Korea \\ ${ }^{2}$ Department of Plant Science, Seoul National University, Seoul 151-921, Korea
}

\begin{abstract}
The objective of this study was to determine the effects of seedling ages of scions and rootstocks for grafting and light intensity during their cultivation in a closed transplant production system on the growth and development of grafted cucumber transplants. Cucumber scions and rootstocks were cultivated under 5 photosynthetic photon flux (PPF) levels: 100, $140,180,230$, and $280 \mu \mathrm{mol} \cdot \mathrm{m}^{-2} \cdot \mathrm{s}^{-1}$ in a closed transplant production system. The scions were grafted onto the rootstocks at $8,9,10,11$, and 12 days after sowing (DAS). Hypocotyl length of scions and rootstocks decreased significantly as PPF increased, and an increase in dry weight with increasing PPF was more pronounced in scions. After grafting, cucumber transplants were grown in a greenhouse until 22 DAS and were then transplanted for investigation of their growth and development. Plant height, leaf area, and fresh weight of cucumber transplants grafted at 8, 9, and 10 DAS were greater, but light intensity during cultivation of scions and rootstocks did not significantly affect the early growth of cucumber transplants after grafting. The number of female flowers in grafted cucumber after transplanting was highest when scions and rootstocks were cultivated under PPF 140 and $180 \mu \mathrm{mol} \cdot \mathrm{m}^{-2} \cdot \mathrm{s}^{-1}$ and were grafted at 8 DAS. These results indicate that controlling environmental conditions in a closed transplant production system during the production of scions and rootstocks can advance grafting time and promote the growth and development of grafted cucumber transplants.
\end{abstract}

Additional key words: controlled environment, Cucumis sativus, grafting, PPF

\section{Introduction}

Grafting has become an essential tool for vegetable production using high tunnels and greenhouse in Korea and Japan for many years in order to overcome issues associated with intensive cultivation using limited arable land (Kubota et al., 2008). It is well-known that the use of grafted transplants can reduce problems involved in successive cropping and stress tolerance (Lee et al., 2010; Schwarz et al., 2010).

The 'closed transplant production system' was developed in Japan in 2000 for the large-scale production of high- quality transplants at a low cost with minimum use of resources (Chun and Kozai, 2000). More recently, closed transplant production system has been commercialized and widely used because of several advantages that include: (1) rapid and efficient growth of transplants due to optimized growth conditions, (2) production of high-quality transplants under uniformly controlled environments, (3) higher productivity per floor area per year due to the use of multilayered shelves, (4) production of disease-free transplants in an area protected from pests and pathogens, and (5) easier control of plant growth and development stages such as stem elongation, bolting, flowering, and root

\footnotetext{
*Comesponding author: changhoo@snu.ac.kr

※ Received 9 March 2014; Revised 9 April 2014; Accepted 29 April 2014. This study was supported by "Cooperative Research Program for Agriculture Science \& Technology Development (Project No.9027022)" of Rural Development Administration, Republic of Korea. We would like to sincerely thank to Yong-Gyo Kim, CEO of Hoban Agricultural Association Cooperation for his support and cooperation. 
formation (Kozai, 2006).

Recently, the annual production of vegetable transplants was recorded to be over 19 billion plants in Korea according to a report from Korean Research Society of Plug Transplant Production in 2009. Lee et al. (2010) reported that grafted cucumber transplants comprised approximately $75 \%$ of all cucumber transplants and that approximately 132 million grafted transplants were needed, assuming the cultivation area for cucumbers in Korea. Cucumbers are usually grafted when the first true leaf appears but is not fully developed in scions and rootstocks. Therefore, determining the most appropriate seedling age for grafting is important for scions and rootstocks (Davis et al., 2008). Production of uniform scions and rootstocks is necessary for successful grafted transplant production and can facilitate use of automation in the grafting process (Kubota et al., 2008). Because a closed transplant production system can precisely control environmental factors, such as light and air temperature, it is suitable for producing scions and rootstocks with uniform sizes and shapes. Optimum seedling age for grafting may differ between species, cultivation systems, and grafting methods. Consequently, it is essential to identify the optimum environmental conditions and to determine the appropriate seedling age of scions and rootstocks for grafting in order to improve the efficiency of production in a closed transplant production system.

The objective of this study was to determine the effects of seedling ages of scions and rootstocks and PPF during their cultivation in a closed transplant production system on the early growth and development of grafted cucumber transplants.

\section{Materials and Methods}

\section{Cultivation of Scions and Rootstocks in a Closed Transplant Production System}

We used Cucumis sativus L. 'Oh My' scions (Wonnong Seeds, Ansung, Korea) and Cucurbita ficifolia 'Heukjong' rootstocks (Seminis Vegetable Seeds Korea, Seoul, Korea) for the preparation of grafted transplants. The seeds for scions and rootstocks were sown in 162- and 128-cell trays filled with a commercial substrate mix (Sunshine Mix; Sun Gro Horticulture, Agawam, MA, USA). The cell trays were placed in a dark room with a controlled air temperature of $28^{\circ} \mathrm{C}$ and $95 \%$ relative humidity for germination.

Three days after sowing (DAS), the seedlings of scions and rootstocks were moved to a closed transplant production system with multi-level shelves and white fluorescent lamps (20 W, Philips Electronics, Amsterdam, The Netherlands).
The cell trays for scions and rootstocks were randomly placed on shelves under five levels of PPF $(100,140,180$, 230 , and $280 \mu \mathrm{mol} \cdot \mathrm{m}^{-2} \cdot \mathrm{s}^{-1}$ ). The photo/dark periods were $10 / 14 \mathrm{~h}$ and the air temperatures during the photo/dark periods were set at $26 / 14^{\circ} \mathrm{C}$. The relative humidity and $\mathrm{CO}_{2}$ concentration in a closed transplant production system were maintained at $60 \%$ and $800 \mu \mathrm{mol} \cdot \mathrm{mol}^{-1}$, respectively. The scions and rootstocks were sub-irrigated every other day with 'Oi Hanbang' nutrient solution (Coseal Co. Ltd., Seoul, Korea) at an EC of $1.3 \mathrm{dS} \cdot \mathrm{m}^{-1}$. Just before grafting, hypocotyl length (stem length below cotyledons), stem diameter, fresh weight, dry weight, and percentage dry matter (dry weight/fresh weight $\times 100 \%$ ) of shoots and roots were measured in scions and rootstocks of each treatment group.

\section{Grafting and Acclimation of Cucumber Transplants}

Grafting was carried out at 8, 9, 10, 11, and 12 DAS. For rootstocks, one cotyledon, the growing point, and the roots were removed. The scions cuttings were grafted onto the rootstock cuttings with clips using the splice grafting method described by Lee et al. (2010). Additional scions and rootstocks were prepared and cultivated conventionally for 12 days (August 12 to 24, 2013) in a greenhouse and grafted by same method as mentioned above. These grafted transplants were used as controls.

The grafted cucumber transplants were rooted in 32-cell trays filled with a commercial substrate mix (Sunshine Mix; Sun Gro Horticulture, Agawam, MA, USA) and then moved to an acclimatization chamber. They were placed under Red + Blue LED lights (red/blue light density ratio: $2 / 1$ ), which were switched on and off every 2 minutes, and irradiated at PPF $50 \mu \mathrm{mol} \cdot \mathrm{m}^{-2} \cdot \mathrm{s}^{-1}$ for 3 days. The air temperature and relative humidity in the chamber were maintained at $28^{\circ} \mathrm{C}$ and $95 \%$, respectively.

\section{Cultivation of Cucumber Transplants in a Greenhouse after Grafting}

After forming the grafted union, cultivation of grafted transplants was carried out at a greenhouse of a commercial propagator located in Chuncheon, Korea (E 127.5', N 37.5). During the first 3 days, grafted transplants were placed in a tunnel with $50 \%$ shade of ambient greenhouse conditions. Then, they were cultivated in a greenhouse and watered once a day. A fertilizer solution (Peter's 20N-20P-20K, The Scotts Co., Marysville, OH, USA) was applied to the plants every other day. For each treatment, plant height, number of leaves, leaf area, and fresh weight of grafted cucumber transplants were measured just before transplanting. 


\section{Cultivation of Cucumber Transplants in a Greenhouse after Transplanting}

Grafted cucumber transplants were transplanted in plastic containers $(800 \times 300 \times 200 \mathrm{~mm}, \mathrm{~L} \times \mathrm{W} \times \mathrm{H})$ filled with a commercial substrate mix (Plant world; Nongwoo Bio Co., Ltd., Suwon, Korea) at 22 DAS. The containers, each containing three plants were arranged in two rows with a plant density of 24 plants $/ \mathrm{m}^{2}$. The plants were grown in a greenhouse located at the experimental field, Seoul National University, Suwon, Korea (E $127.0^{\circ}, \mathrm{N} 37.3^{\circ}$ ) for 28 days (from September 3 to October 1, 2013). They were drip-irrigated twice per day with 'Oi Hanbang' nutrient solution (Coseal Co., Ltd., Seoul, Korea) and the EC of the nutrition solution was $2.5 \mathrm{dS} \cdot \mathrm{m}^{-1}$. We investigated the total number of internodes, the number of internodes under the point of first flowering, and the number of female flowers at 50 DAS.

\section{Statistical Analysis}

The experimental data were analyzed using SAS statistical software (SAS Institute, Cary, USA) and differences between treatments were assessed by Duncan's multiple range tests $(p \leq 0.05)$.

\section{Results and Discussion}

\section{Quality of Scions and Rootstocks as Affected by PPF and Seedling Age}

In scions, increasing PPF significantly decreased hypocotyl length and increased stem diameter, dry weight, and percentage dry matter (Table 1). In rootstocks, hypocotyl length decreased with increasing PPF, while stem diameter and dry weight were not affected by PPF (Table 2). Increasing seedling age increased the dry weight of the shoots and roots of scions and rootstocks, and an increase in PPF was associated with an increase in the percentage dry matter of shoots and roots of scions regardless of seedling age.

Light intensity is one of the most important environmental factors affecting growth and quality of transplants (Kitaya et al., 1998). Increasing light intensity suppressed stem elongation and increased the stem diameter of scions, and the results obtained in this study support previous reports on a similar subject matter (Butler, 1963; Kozai et al., 1995). The effect of light intensity on dry weight and percentage dry matter was more pronounced in scions. It is well known that more intense light increases dry weight due to the increased carbon assimilation rate through photosynthesis (Mosaleeyanon et al., 2005; Nemali and van Iersel, 2004). These data indicate that scions are more efficient to assimilate carbon products through photosynthesis because scions have been selected on the basis of its efficacy for vigorous shoot growth and high fruit quality.
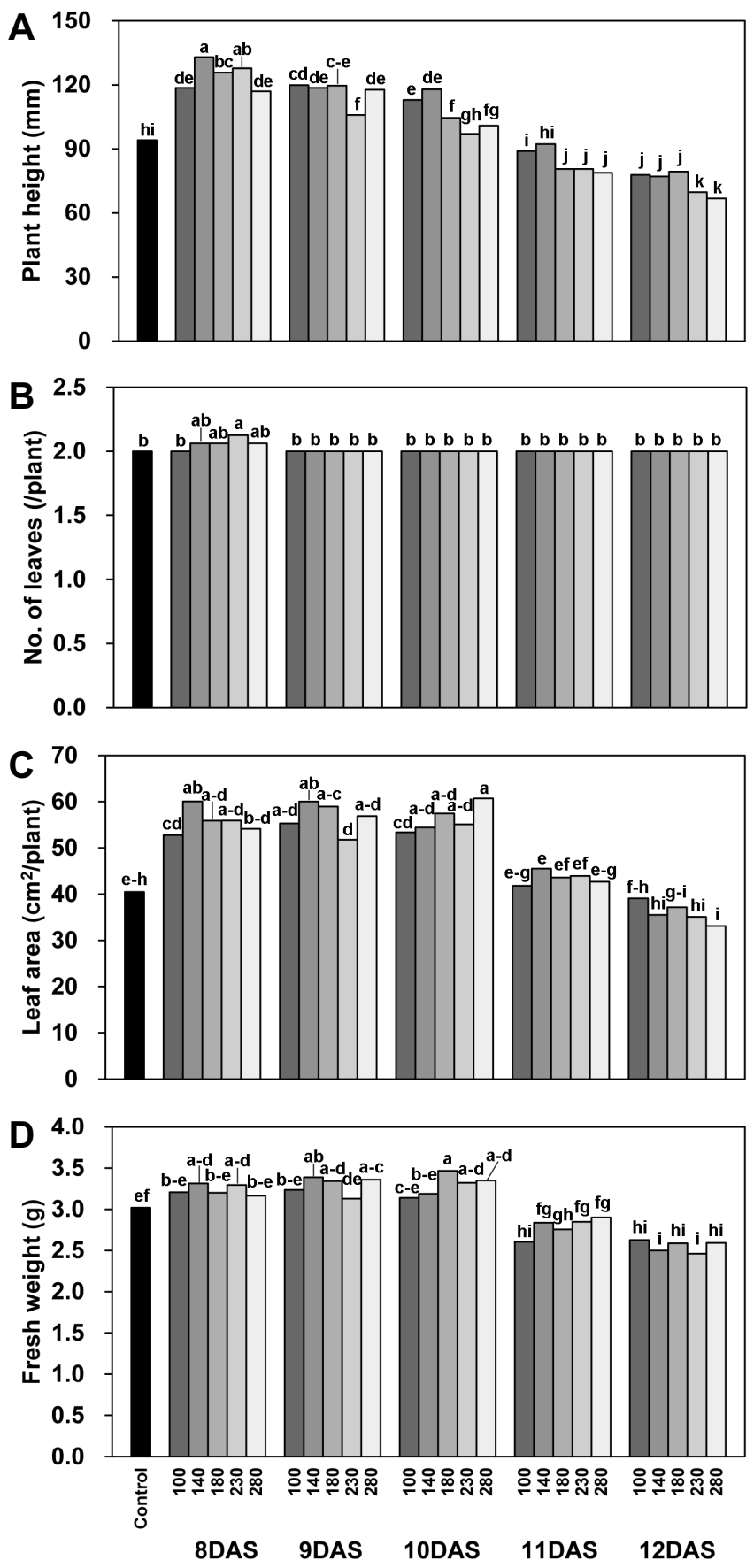

Fig. 1. The effects of seedling age (days after sowing, DAS) and PPF during the production of scions and rootstocks in a closed transplant production system on plant height (A), number of leaves (B), leaf area (C), and fresh weight (D) of grafted cucumber transplants 22 days after sowing. 
Table 1. Hypocotyl length, stem diameter, fresh weight, dry weight, and percentage dry matter of scions as affected by seedling age (days after sowing, DAS) and PPF in a closed transplant production system.

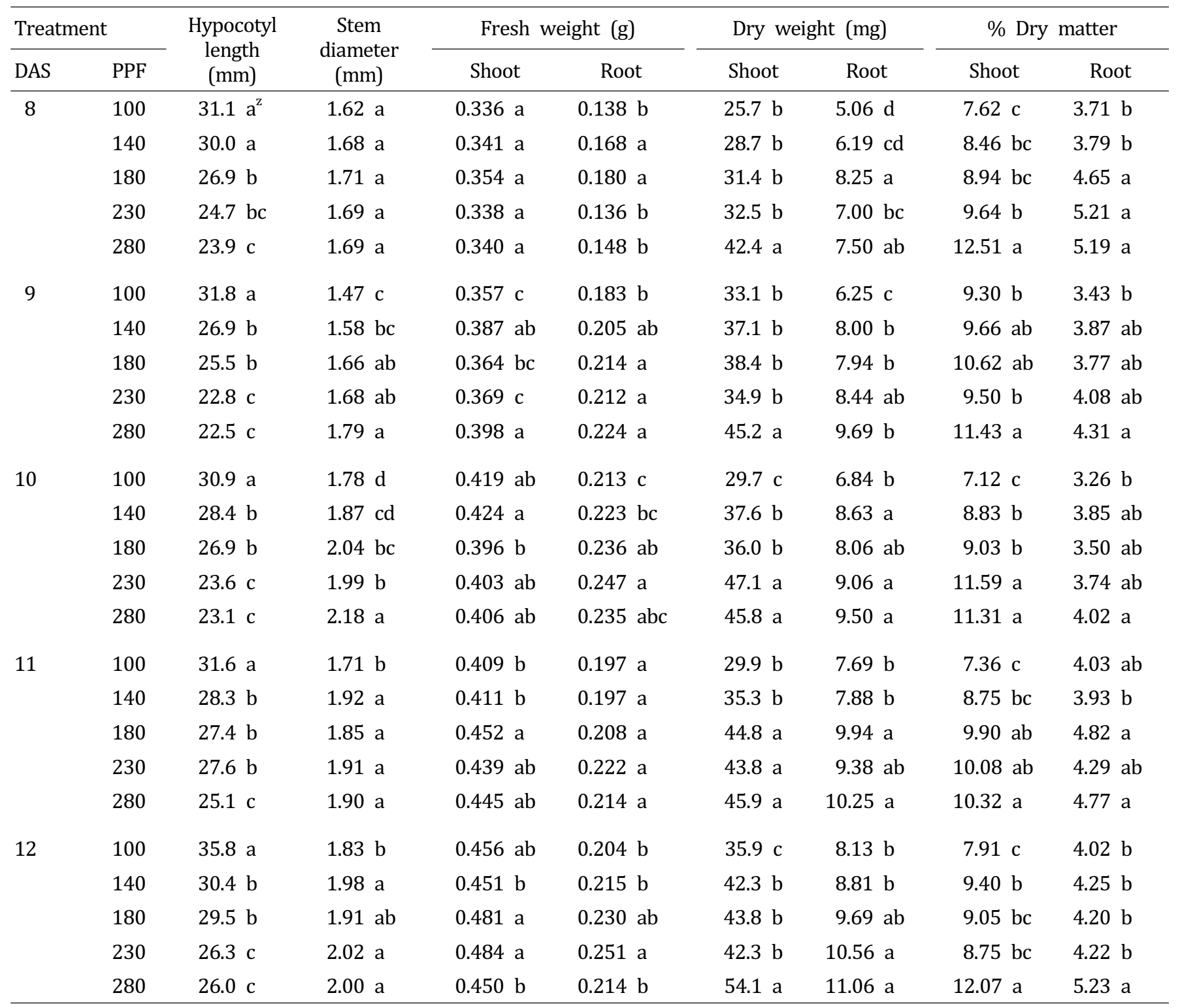

${ }^{\mathrm{z}}$ Means in columns followed by different letters are significantly different by Duncan's multiple range tests at $p \leq 0.05$.

\section{Early Growth of Cucumber Transplants Grown in a Greenhouse after Grafting}

When scions were grafted onto rootstocks at 8, 9, and 10 DAS, plant height, leaf area, and fresh weight of cucumber transplants were greater than those of the control group (Fig. 1). The scions and rootstocks in the control group were conventionally cultivated in a greenhouse, and cucumber transplants were grafted at 12 DAS. Although cucumber transplants were grafted at same time (12 DAS), the growth of cucumber transplants that has been grafted using the scions and rootstocks cultivated in a closed transplant production system was less than that of the control group. Increasing PPF during the production of scions and rootstocks in a closed transplant production system increased dry weight of scions and rootstocks, while the growth of cucumber transplants grown in a greenhouse after grafting was not significantly affected by light intensity during the production of scions and rootstocks.

After grafting, the callus formed at the grafted interface develops vascular bundles allowing the flow of water and 
Table 2. Hypocotyl length, stem diameter, fresh weight, dry weight, and percentage dry matter of rootstocks as affected by seedling age (days after sowing, DAS) and PPF in a closed transplant production system.

\begin{tabular}{|c|c|c|c|c|c|c|c|c|c|}
\hline \multicolumn{2}{|c|}{ Treatment } & \multirow{2}{*}{$\begin{array}{l}\text { Hypocotyl } \\
\text { length } \\
\text { (mm) }\end{array}$} & \multirow{2}{*}{$\begin{array}{l}\text { Stem } \\
\text { diameter } \\
(\mathrm{mm})\end{array}$} & \multicolumn{2}{|c|}{ Fresh weight (g) } & \multicolumn{2}{|c|}{ Dry weight (mg) } & \multicolumn{2}{|c|}{$\%$ Dry matter } \\
\hline DAS & PPF & & & Shoot & Root & Shoot & Root & Shoot & Root \\
\hline \multirow[t]{5}{*}{8} & 100 & $52.3 \mathrm{a}$ & $3.10 \mathrm{a}$ & $1.329 \mathrm{a}$ & $0.572 \mathrm{a}$ & $123 \mathrm{a}$ & $24.4 \mathrm{a}$ & $9.68 \mathrm{ab}$ & $4.30 \mathrm{~b}$ \\
\hline & 140 & $51.4 \mathrm{a}$ & $2.95 \mathrm{a}$ & $1.246 \mathrm{a}$ & $0.416 \mathrm{c}$ & $120 \mathrm{a}$ & $20.6 \mathrm{~b}$ & $9.19 \mathrm{ab}$ & $4.92 \mathrm{ab}$ \\
\hline & 180 & $42.9 \mathrm{~b}$ & $3.08 \mathrm{a}$ & $1.342 \mathrm{a}$ & $0.401 \mathrm{c}$ & $112 \mathrm{a}$ & $20.1 \mathrm{~b}$ & $8.45 \mathrm{~b}$ & $5.13 \mathrm{a}$ \\
\hline & 230 & $40.5 \mathrm{~b}$ & $2.79 \mathrm{a}$ & $1.269 \mathrm{a}$ & $0.492 \mathrm{~b}$ & $118 \mathrm{a}$ & $20.8 \mathrm{~b}$ & $9.41 \mathrm{ab}$ & $4.28 \mathrm{~b}$ \\
\hline & 280 & $33.9 \mathrm{c}$ & $3.07 \mathrm{a}$ & $1.248 \mathrm{a}$ & $0.486 \mathrm{~b}$ & $123 \mathrm{a}$ & $20.6 \mathrm{~b}$ & $9.86 \mathrm{a}$ & $4.29 \mathrm{~b}$ \\
\hline \multirow[t]{5}{*}{9} & 100 & $56.7 \mathrm{a}$ & $2.67 \mathrm{~b}$ & $1.502 \mathrm{ab}$ & $0.525 \mathrm{~b}$ & $112 \mathrm{~b}$ & $22.8 \mathrm{ab}$ & $7.48 \mathrm{c}$ & $4.36 \mathrm{a}$ \\
\hline & 140 & $54.4 \mathrm{a}$ & $3.08 \mathrm{a}$ & $1.598 \mathrm{a}$ & $0.536 \mathrm{~b}$ & $117 \mathrm{~b}$ & $22.3 \mathrm{~b}$ & $7.35 \mathrm{c}$ & $4.22 \mathrm{a}$ \\
\hline & 180 & $43.3 \mathrm{~b}$ & $3.21 \mathrm{a}$ & $1.497 \mathrm{ab}$ & $0.552 \mathrm{~b}$ & $120 \mathrm{ab}$ & $21.7 \mathrm{~b}$ & $8.01 \mathrm{~b}$ & $3.97 \mathrm{a}$ \\
\hline & 230 & $43.0 \mathrm{~b}$ & $2.88 \mathrm{ab}$ & $1.478 \mathrm{ab}$ & $0.562 \mathrm{ab}$ & $112 \mathrm{~b}$ & $21.8 \mathrm{~b}$ & $7.59 \mathrm{bc}$ & $3.92 \mathrm{a}$ \\
\hline & 280 & $35.9 \mathrm{c}$ & $3.20 \mathrm{a}$ & $1.420 \mathrm{~b}$ & $0.637 \mathrm{a}$ & $129 \mathrm{a}$ & $25.4 \mathrm{a}$ & $9.15 \mathrm{a}$ & $4.10 \mathrm{a}$ \\
\hline \multirow[t]{5}{*}{10} & 100 & $60.6 \mathrm{a}$ & $2.66 \mathrm{a}$ & $1.808 \mathrm{a}$ & $0.513 \mathrm{~b}$ & $135 \mathrm{a}$ & $23.5 \mathrm{~b}$ & $7.50 \mathrm{c}$ & $4.57 \mathrm{a}$ \\
\hline & 140 & $54.3 \mathrm{~b}$ & $2.85 \mathrm{a}$ & $1.736 \mathrm{ab}$ & $0.462 \mathrm{~b}$ & $136 \mathrm{a}$ & $22.1 \mathrm{~b}$ & $7.83 \mathrm{c}$ & $4.81 \mathrm{a}$ \\
\hline & 180 & $45.1 \mathrm{c}$ & $2.86 \mathrm{a}$ & $1.622 \mathrm{~b}$ & $0.494 \mathrm{~b}$ & $137 \mathrm{a}$ & $23.4 \mathrm{~b}$ & $8.47 \mathrm{ab}$ & $4.77 \mathrm{a}$ \\
\hline & 230 & $43.3 \mathrm{c}$ & $2.87 \mathrm{a}$ & $1.603 \mathrm{~b}$ & $0.479 \mathrm{~b}$ & $133 \mathrm{a}$ & $23.6 \mathrm{~b}$ & $8.32 \mathrm{~b}$ & $4.95 \mathrm{a}$ \\
\hline & 280 & $34.4 \mathrm{~d}$ & $2.82 \mathrm{a}$ & $1.620 \mathrm{~b}$ & 0.606 a & $141 \mathrm{a}$ & $27.3 \mathrm{a}$ & $8.71 \mathrm{a}$ & $4.55 \mathrm{a}$ \\
\hline \multirow[t]{5}{*}{11} & 100 & 56.6 a & $2.52 \mathrm{a}$ & $1.725 \mathrm{a}$ & $0.533 \mathrm{~b}$ & 129 a & $26.5 \mathrm{a}$ & $7.47 \mathrm{~b}$ & $5.03 \mathrm{ab}$ \\
\hline & 140 & $50.1 \mathrm{~b}$ & $2.54 \mathrm{a}$ & $1.646 \mathrm{ab}$ & 0.412 c & $127 \mathrm{a}$ & $22.0 \mathrm{~b}$ & $7.74 \mathrm{~b}$ & $5.60 \mathrm{a}$ \\
\hline & 180 & $43.2 \mathrm{c}$ & $2.59 \mathrm{a}$ & $1.603 \mathrm{ab}$ & $0.464 \mathrm{bc}$ & $131 \mathrm{a}$ & $22.4 \mathrm{~b}$ & $8.17 \mathrm{a}$ & $4.97 \mathrm{ab}$ \\
\hline & 230 & $40.3 \mathrm{~cd}$ & $2.53 \mathrm{a}$ & $1.575 \mathrm{~b}$ & $0.498 \mathrm{~b}$ & $129 \mathrm{a}$ & $25.1 \mathrm{a}$ & $8.20 \mathrm{a}$ & $5.16 \mathrm{ab}$ \\
\hline & 280 & $36.1 \mathrm{~d}$ & $2.58 \mathrm{a}$ & $1.518 \mathrm{~b}$ & $0.625 \mathrm{a}$ & $129 \mathrm{a}$ & $27.5 \mathrm{a}$ & $8.48 \mathrm{a}$ & $4.49 \mathrm{~b}$ \\
\hline \multirow[t]{5}{*}{12} & 100 & $54.6 \mathrm{ab}$ & $2.67 \mathrm{a}$ & $1.793 \mathrm{a}$ & $0.513 \mathrm{a}$ & 149 a & $25.9 \mathrm{bc}$ & $8.29 \mathrm{~b}$ & $5.11 \mathrm{bc}$ \\
\hline & 140 & $51.2 \mathrm{~b}$ & $2.52 \mathrm{~b}$ & $1.572 \mathrm{~b}$ & $0.398 \mathrm{~b}$ & $146 \mathrm{a}$ & $23.4 \mathrm{c}$ & $9.44 \mathrm{a}$ & $6.20 \mathrm{a}$ \\
\hline & 180 & $39.4 \mathrm{a}$ & $2.83 \mathrm{a}$ & $1.787 \mathrm{a}$ & $0.542 \mathrm{a}$ & $141 \mathrm{a}$ & $24.1 \mathrm{c}$ & $7.91 \mathrm{~b}$ & $4.48 \mathrm{c}$ \\
\hline & 230 & $36.8 \mathrm{a}$ & $2.82 \mathrm{~b}$ & $1.607 \mathrm{a}$ & 0.499 a & 149 a & $29.6 \mathrm{a}$ & $9.31 \mathrm{a}$ & $5.98 \mathrm{ab}$ \\
\hline & 280 & $33.2 \mathrm{ab}$ & $2.70 \mathrm{~b}$ & $1.566 \mathrm{a}$ & $0.541 \mathrm{a}$ & $148 \mathrm{a}$ & $27.1 \mathrm{ab}$ & $9.44 \mathrm{a}$ & $5.05 \mathrm{bc}$ \\
\hline
\end{tabular}

${ }^{\mathrm{z}}$ Means in columns followed by different letters are significantly different by Duncan's multiple range tests at $p \leq 0.05$.

nutrients from rootstock to scion (Moore, 1984). Wright (1893) reported that there is a certain stage of growth in which plants may be easily grafted. In much younger plants, the tissues are not strong enough to survive the injuries inflicted during the operation, while in older plants the activity of cell division is generally low. Our results suggest that the scions and rootstocks cultivated for 11 and 12 DAS in a closed transplant production system were past the optimal growth stage for grafting, and that the initiation and development of vascular bundles occurs slowly. Previous studies have also reported a decrease in survival rate and growth after grafting in older plants (Greenwood, 1984; Johkan et al., 2008, 2009). Chang et al. (2000) reported that the relative growth rates of watermelon transplants at the early days after grafting increased with decreasing seedling ages of scions and rootstocks.

Although cucumber transplants were grafted at the same time, the cultivation system of scions and rootstocks affected the growth of cucumber transplants grown in a greenhouse after grafting. Plant growth was significantly higher in the 
plants grown in the controlled environments than in those grown in a greenhouse due to the optimal environmental conditions provided by a closed transplant production system (Mosaleeyanon et al., 2005). Our data indicate that the growth stage of scions and rootstock differed between those grown in a greenhouse and those grown in a closed transplant production system, even if the scions and rootstocks were cultivated for the same period.

\section{Development of Cucumber Transplants Grown in a Greenhouse after Transplanting}

Considering the results of the early growth after grafting, we transplanted cucumber transplants grafted at 8, 9, and 10 DAS. And, the cucumber transplants in the high PPF treatments $\left(230\right.$ and $\left.280 \mu \mathrm{mol} \cdot \mathrm{m}^{-2} \cdot \mathrm{s}^{-1}\right)$ were excluded from transplanting, because an increase in PPF did not significantly promote the growth of cucumber transplants. Increasing light intensity requires more electric power for lighting and cooling, which causes an increase in the cost of plant production in a closed transplant production system (Ohyama and Kozai, 1998).

When scions and rootstocks were cultivated at PPF 140 and $180 \mu \mathrm{mol} \cdot \mathrm{m}^{-2} \cdot \mathrm{s}^{-1}$ and the scions were grafted onto the rootstocks at 8 DAS, the number of female flowers was highest 28 days after transplanting (Table 3). The number of female flowers was lowest in the control plants, and there were no significant differences between treatments in the total number of internodes or in the number of internodes under the point of first flowering. Proper floral development is one of the important factors that affect the quality of vegetable transplants (Ohyama et al., 2005). Many researchers have reported that the quality of transplants with respect to the floral development was affected by environment conditions during transplant production (Grimstad, 1993; Ohyama et al., 2003; Saito and Ito, 1962). Ohyama et al. (2003) reported that the number of internodes below the first truss in tomato transplants cultivated in a closed transplant production system was lower than that in tomato transplants cultivated in a greenhouse.

Low temperature and short day enhanced the femaleness of cucumber plants. In the control group, the scions were grown in a greenhouse from August 12 to August 24, 2013; the day length was long and the minimum air temperature was high (about $23.5^{\circ} \mathrm{C}$ ) during this period. In a closed transplant production system, however, the scions were grown in a $10 \mathrm{~h}$ photoperiod and a $26 / 14^{\circ} \mathrm{C}$ air temperature in the photo/dark period. Fujieda (1966) reported that cucumber plants already have differentiated flower primordia up to the 9th, 12th, and 15th internodes at the first, second, and third leaf stages, respectively. He also showed that the short day treatment for 10 days at the cotyledonary stage could somewhat accelerate the formation of female flowers. It was supposed that the favorable environmental conditions in a closed transplant production system during the production of scions promoted the development of grafted cucumber transplants after transplanting.

In conclusion, our results showed that the scions and rootstocks suitable for grafting could be produced at relatively low PPFs in a closed transplant production system, and the period required for production of scions and rootstocks

Table 3. The effects of seedling age (days after sowing, DAS) and PPF during production of scions and rootstocks in a closed transplant production system on the development of grafted cucumber transplants 28 days after transplanting.

\begin{tabular}{llccr}
\hline Treatment & PAS & $\begin{array}{c}\text { Total number of internodes } \\
\text { (/plant) }\end{array}$ & $\begin{array}{c}\text { Number of internodes under the } \\
\text { point of first flowering (/plant) }\end{array}$ & $\begin{array}{c}\text { Number of female flowers } \\
\text { (/plant) }\end{array}$ \\
\hline 8 & 100 & $14.4 \mathrm{a}^{\mathrm{z}}$ & $3.0 \mathrm{a}$ & $8.3 \mathrm{bc}$ \\
& 140 & $15.4 \mathrm{a}$ & $3.2 \mathrm{a}$ & $10.1 \mathrm{a}$ \\
& 180 & $15.3 \mathrm{a}$ & $3.5 \mathrm{a}$ & $9.4 \mathrm{a}$ \\
9 & 100 & $15.3 \mathrm{a}$ & $3.7 \mathrm{a}$ & $9.7 \mathrm{ab}$ \\
& 140 & $14.7 \mathrm{a}$ & $3.4 \mathrm{a}$ & $9.0 \mathrm{abc}$ \\
10 & 180 & $15.3 \mathrm{a}$ & $3.7 \mathrm{a}$ & $9.7 \mathrm{ab}$ \\
& 100 & $15.2 \mathrm{a}$ & $3.5 \mathrm{a}$ & $9.2 \mathrm{abc}$ \\
& 140 & $15.0 \mathrm{a}$ & $3.3 \mathrm{a}$ & $9.1 \mathrm{abc}$ \\
& 180 & $14.6 \mathrm{a}$ & $3.3 \mathrm{a}$ & $8.0 \mathrm{c}$ \\
\hline
\end{tabular}

\footnotetext{
${ }^{\mathrm{z}}$ Means in columns followed by different letters are significantly different by Duncan's multiple range tests at $p \leq 0.05$.
} 
suitable for grafting could be reduced in a closed transplant production system. Furthermore, we confirmed that the early growth and development of grafted cucumber transplants could be promoted by producing scions and rootstocks under controlled environmental conditions in a closed transplant production system.

\section{Literature Cited}

Butler, R.D. 1963. The effect of light intensity on stem and leaf growth in broad bean seedlings. J. Exp. Bot. 14:142-152.

Chang, Y.H., C.Y. Cho, C.W. Ro, and J.L. Cho. 2000. Effect of root-cut graft time on seedling growth in watermelon plug products. J. Kor. Hort. Sci. Technol. 18(Suppl. II):167. (Abstr.)

Chun, C. and T. Kozai. 2000. Closed transplant production system at Chiba University, p. 20-27. In: C. Kubota and C. Chun (eds.). Transplant production in the $21^{\text {st }}$ century. Kluwer publishers, Dordrecht, The Netherlands.

Davis, A.R., P. Perkins-Veazie, Y. Sakata, S. López-Galarza, J.V. Maroto, S.G. Lee, Y.C. Huh, Z. Sun, A. Miguel, S.R. King, R. Cohen, and J.M. Lee. 2008. Cucurbit grafting. Crit. Rev. Plant Sci. 27:50-74.

Fujieda, K. 1966. A genecological study on the differentiation of sex expression in cucumber plants. Bul. Hortic. Res. Sta. Ser. D 4:43-86.

Greenwood, M.S. 1984. Phase change in loblolly pine: Shoot development as a function of age. Physiol. Plant 61:518-522.

Grimstad, S.O. 1993. The effect of a daily low temperature pulse on growth and development of greenhouse cucumber and tomato plants during propagation. Sci. Hortic. 53:53-62.

Johkan, M., K. Mitukuri, S. Yamasaki, G. Mori, and M. Oda. 2009. Causes of defoliation and low survival rate of grafted sweet pepper plants. Sci. Hortic. 119:103-107.

Johkan, M., M. Oda, and G. Mori. 2008. Ascorbic acid promotes graft-take in sweet pepper plants (Capsicum annuum L.). Sci. Hortic. 116:343-347.

Kitaya, Y., G. Niu, T. Kozai, and M. Ohashi. 1998. Photosynthetic photon flux, photoperiod, and $\mathrm{CO}_{2}$ concentration affect growth and morphology of lettuce plug transplants. HortScience 33:988-991.

Kozai, T. 2006. Closed systems for high quality transplants using minimum resources, p. 275-312. In: S.D. Gupta and Y. Ibaraki (eds.). Plant tissue culture engineering. Springer, Dordrecht, The Netherlands.
Kozai, T., K. Watanabe, and B.R. Jeong. 1995. Stem elongation and growth of Solanum tuberosum L. in vitro in response to photosynthetic photon flux, photoperiod and difference in photoperiod and dark period temperatures. Sci. Hortic. 64:1-9.

Kubota, C., M.A. McClure, N. Kokalis-Burelle, M.G. Bausher, and E.N. Rosskopf. 2008. Vegetable grafting: History, use, and current technology status in North America. HortScience 43:1664-1669.

Lee, J.M., C. Kubota, S.J. Tsao, Z. Bie, P. Hoyos Echevarria, L. Morra, and M. Oda. 2010. Current status of vegetable grafting: Diffusion, grafting techniques, automation. Sci. Hortic. 127:93-105.

Moore, R. 1984. A model for graft compatibility-incompatibility in higher plants. Am. J. Bot. 71:752-758.

Mosaleeyanon, K., S.M.A. Zobayed, F. Afreen, and T. Kozai. 2005. Relationships between net photosynthetic rate and secondary metabolite contents in St. John's wort. Plant Sci. 169:523-531.

Nemali, K.S. and M.W. van Iersel. 2004. Light intensity and fertilizer concentration: II. Optimal fertilizer solution concentration for species differing in light requirement and growth rate. HortScience 39:1293-1297.

Ohyama, K., K. Manabe, Y. Omura, and T. Kozai. 2005. Potential use of a 24-hour photoperiod (continuous light) with altering air temperature for production of tomato plug transplants in a closed system. HortScience 40:374-377.

Ohyama, K., K. Manabe, Y. Omura, C. Kubota, and T. Kozai. 2003. A comparison between closed-type and open-type transplant production systems with respect to quality of tomato plug transplants and resource consumption during summer. Environ. Control Biol. 41:57-61.

Ohyama, K. and T. Kozai. 1998. Estimating electric energy consumption and its cost in a transplant production factory with artificial lighting: A case study. J. Soc. High Technol. Agri. 10:96-107.

Saito, T. and H. Ito. 1962. Studies on the growth and fruiting in the tomato, I. Effect of the early environment on the growth and fruiting, I. (1) Thermoperiods. J. Jpn. Soc. Hortic. Sci. 31:303-314

Schwarz, D., Y. Rouphael, G. Colla, and J.H. Venema. 2010. Grafting as a tool to improve tolerance of vegetables to abiotic stress: Thermal stress, water stress and organic pollutants. Sci. Hortic. 127:162-171.

Wright, J.S. 1893. Cell union in herbaceous grafting. Botanical Gazette 18:285-293. 